\title{
Study of Electrical and Magnetic Properties in Nano sized Ce-Gd Doped Magnesium Ferrite
}

\author{
Vasant Naidu \\ Professor/ECE \\ Sethu Inst. of Tech., \\ Pulloor - 626115, \\ Tamilnadu, India
}

\author{
S.K.A. Ahamed \\ Kandu Sahib \\ Asso.Professor./ \\ ECE,Sethu Inst. of \\ Tech. Pulloor 626-115, \\ Tamilnadu, India
}

\author{
M.Suganthi \\ Professor/ECE \\ Thiagarajar College of \\ Engine-ering, Madurai \\ 625 015, Tamilnadu, \\ India
}

\author{
Chandra Prakash \\ Additional Director \\ D.R.D.O, \\ New Delhi-110 011, \\ India
}

\begin{abstract}
Nano crystalline magnesium Cerium Gadolinium ferrite with general formula $\mathrm{Mg} \mathrm{Ce}_{\mathrm{x}} \mathrm{Gd}_{\mathrm{y}} \mathrm{Fe}_{2-\mathrm{x}-\mathrm{y}} \mathrm{O}_{4}$ (where $\mathrm{x}=0.001$, $0.012,0.016,0.018$ and $\mathrm{y}=0.002$ ) were prepared through solgel route from high purity nitrates of Magnesium $(\mathrm{Mg})$, Cerium(Ce), Gadolinium(Gd) and Iron. The samples were sintered in microwave furnace and then characterized by XRD, EDAX, FTIR and SEM techniques. X-ray diffraction measurements confirmed the Nano size and formation of single phase cubic spinel structure of magnesium ferrite. It was found that the lattice constant decreases with the increase in $\mathrm{Gd}^{3+} \mathrm{Ce}^{3+}$ concentration and the crystalline size of the samples was lying in the range of $53.24-53.78 \mathrm{~nm}$, which was confirmed from the SEM monographs. SEM studies show that the grain size of the samples decreases with the increase in $\mathrm{Gd}^{3+} \mathrm{Ce}^{3+}$ content. The FTIR spectra shows two strong absorption bands within the frequency range of $362.59-570.89 \mathrm{~cm}^{-1}$. This concludes that $\mathrm{Gd}^{3+}, \mathrm{Ce}^{3+}$ occupies B-site. Saturation magnetization of $\mathrm{Gd}^{3+} \mathrm{Ce}^{3+}$ substituted $\mathrm{Mg}$ ferrites is higher than unsubstituted ferrite. The VSM studies confirm the magnetic behaviour and used to understand the electromagnetic properties of these nano materials. The permittivity studies show the decrease in relative permittivity of the material.
\end{abstract}

Keywords: Nanomaterials, EDAX, relative permittivity, VSM, saturation magnetization.

\section{INTRODUCTION}

Magnesium ferrites have attracted much attention in recent years as one of the candidates for high density magnetic recording [1-5], microwave absorbents, sensors and electronic device, high frequency devices, color imaging etc [6-8], because it has high magnetic permeability and high electrical resistance. Many research groups have investigated to enhance the magnetic properties of magnesium ferrites $\mathrm{Mg}$ represents the divalent transition metal, hence the magnetic properties of spinel ferrites can be varied systematically by changing the identity of the divalent $\mathrm{Mg}^{2+}$ cations without chan ging the spinel crystal structure [1]. It is well known that the chemical, structural, and magnetic properties of spinel ferrites nano particles are strongly influenced by their composition and micro structures, which are sensitive to the preparation methodologies. Khan and Zhang [9] showed that

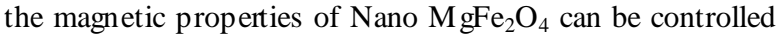
by doping the spinel ferrite with lanthanide ( $\mathrm{Ce}$ or $\mathrm{Gd}$ ) up to the mole ratio of 0.12 . The present work reports the influence of rare-earth ion $(\mathrm{Ce}-\mathrm{Gd})$ on the structural behaviour and magnetic properties of $\mathrm{MgFe}_{2} \mathrm{O}_{4}$. These Magnesium ferrites were prepared by sol gel route [1] for maintaining low coercivity and low permittivity.

\section{EXPERIMENTAL PROCEDURE}

\subsection{Synthesis Technique}

Nanocry stalline powders of $\mathrm{Mg} \mathrm{Ce}_{\mathrm{x}} \mathrm{Gd}_{\mathrm{y}} \mathrm{Fe}_{2-\mathrm{x}-\mathrm{y}} \mathrm{O}_{4}$ (where $\mathrm{x}$ $=0.001,0.012,0.016,0.018$ and $\mathrm{y}=0.002$ ) were prepared by sol-gel auto-combustion route. All the chemical used were of A.R Grade - Citric acid $\left[\mathrm{C}_{6} \mathrm{H}_{8} \mathrm{O}_{7} \cdot \mathrm{H}_{2} \mathrm{O}\right]$ Merck, Ferric Nitrate $\left[\mathrm{Fe}\left(\mathrm{NO}_{3}\right)_{3} \cdot 9 \mathrm{H}_{2} \mathrm{O}\right] \mathrm{Merck}$, Magnesium nitrate $\left[\mathrm{Mg}\left(\mathrm{NO}_{3}\right)_{2} \cdot \mathrm{H}_{2} \mathrm{O}\right]$ Lobo Chem., Cerium Nitrate $\left[\mathrm{Ce}\left(\mathrm{NO}_{3}\right)_{2} \cdot \mathrm{H}_{2} \mathrm{O}\right]$ Alfa Aesar and Gadolinium nitrate $\left[\mathrm{Gd}\left(\mathrm{NO}_{3}\right)_{3} \cdot \mathrm{XH}_{2} \mathrm{O}\right]$ Alfa Aesar.

The required amount of metal nitrates and citric acid are taken so as to have a molar ratio of 1:1 [1]. Gd and Ce atoms are substituted for $\mathrm{Fe}$ atoms at $\mathrm{x}$ and $\mathrm{y}$ ratio respectively, where as $\mathrm{x}$ is varied for $0.001,0.012,0.016,0.018$ and $\mathrm{y}$ was taken as 0.002 and dissolved in $100 \mathrm{ml}$ of de-ionized water the required amount of ammonia solution was slowly added to adjust the $\mathrm{pH}$ to 7 . The mixed solution was heated and burnt on a hot plate with continuous heating at a temperature of $94^{\circ} \mathrm{C}$. The viscous brown gel burnt with glowing flints. The auto ignition was completed within a minute, yielding into a brown-colored ash. The as-prepared powders of all the sample were sintered in a microwave furn ace VBCC/MF to a temperature of $850^{\circ} \mathrm{C}$ for 1.5 hours [5]. The grain size of the nanoferrite was determined using Scherrer's equation. The FWHM value of the peak corresponding to a plane was considered after correction for instrumental broadening. The experimental magnetic moment was calculated from the following formula $[10,5]$.

$$
\eta=\frac{\left[\mathrm{M}_{W} \times \mathrm{M}_{\mathrm{S}}\right]}{5585}
$$

Where $\mathrm{M}_{\mathrm{W}}$ is the molecular weight of the sample and $\mathrm{Ms}$ is the saturation magnetization in $\mathrm{emu} / \mathrm{g}$ obtained from the VSM data

\subsection{XRD and EDAX Studies}

To study the phase and crystallinity of the nano material XRD studies were performed on PAN analytical X'pert PRO and EDAX studies were done on Genesis EDAX to confirm the presence of elements in the powder.

\subsection{FTIR Study}

The interpretation of the results was done by studying the spectrum transmittance $(\%)$ against wave number $\left(\mathrm{m}^{-1}\right)$ .Within the range of $362.59-570.89 \mathrm{~cm}^{-1}$ infrared absorption spectra were recorded at room temperature by using SHIM ADZU FTIR spectrum one spectrometer using $\mathrm{KBr}$ pellet method.

\subsection{SEM Studies}

Scanning Electron microscope (SEM) micrographs of the nano ferrite material was recorded using a scanning electron microscope (HITACHI model S-3000H). These SEM 
micrographs were used to estimate the nano size of the material particles

\subsection{Magnetic Measure ments}

The commercial vibrating sample magnetometer (VSM) Lakeshore (Model73009) was used for the Magnetic measurements. The maximum applied magnetic fields was $0.95 \mathrm{~T}$ to obtain the magnetic hysteresis loops at the room temperature at an interval of $2.5 \mathrm{hrs}$. The saturation magnetization, coercivity and remanent magnetization were found from hysteresis loops.

\subsection{Electrical Measure ments}

The Electrical measurements were performed using the N4L LCR meter. The experimental set up for measuring the dielectric properties in the microwave region consisted of a pallet holder connected to the N4L LCR meter interfacing the computer [11]. The microwave properties of the four samples $\mathrm{Ce}(\mathrm{x})-\mathrm{Gd}(\mathrm{y})$ doped magnesium ferrite $\mathrm{x}=0.001,0.012$, $0.016,0.018$ and $y=0.002$, were investigated at the frequency range from $20 \mathrm{KHz}$ to $20 \mathrm{MHz}$

\subsection{RESULTS AND DISCUSSION \\ 3.1 X-ray diffraction}

The broader peaks of XRD indicated the fine crystalline size of the ferrite powder and the phase formation behaviour of $\mathrm{MgCe}_{\mathrm{x}} \mathrm{Gd}_{\mathrm{y}} \mathrm{Fe}_{2-\mathrm{x}-\mathrm{y}} \mathrm{O}_{4}$ in the XRD Fig 1 .

As the Fig.1 shows the $\mathrm{X}$-ray diffraction patterns of as burnt ferrite powder of different composition of $\mathrm{Mg} \mathrm{Ce}_{\mathrm{x}} \mathrm{Gd}_{\mathrm{y}} \mathrm{Fe}_{2-\mathrm{x}-\mathrm{y}}$ $\mathrm{O}_{4}$, The XRD patterns were similar to the JCPDS card number 89-3084 for magnesium ferrite powder and peaks of $\mathrm{Ce}$ and Gd are marked in the XRD, which are in accordance to JCPDS card number 75-0161. The figure conform the absence of metal oxide phase in the as burnt powder. The $\mathrm{X}$ ray pattern shows reflection plane (220), (311), (222) (400), (422), and (440). It was also observed that the appearance of plane (222) is there in all the sample patterns, which clearly indicates the presence of $\mathrm{MgFe}_{2} \mathrm{O}_{4}$ in single-phase cubic spinel structure.

The secondary phase (orthorhombic) was also observed due to the presence of rare-earth ortho-ferrite $\left(\mathrm{CeFeO}_{3}\right)$. The presence of secondary phase also suggest the solubility limit of $\mathrm{Ce}^{3+}$ ions in the spinel lattice due to its radius $(0.083 \mathrm{~nm}$, $0.095 \mathrm{~nm}$, and $0.115 \mathrm{~nm}$ ) [12].

It was well known that the degree of replacement of the host cations by the other ions in the host lattice depending on the cations radius of the substituent [13]. The lattice constant $a$ $\left(\mathrm{A}^{\circ}\right)$ in the spinel structure are mentioned in Table 1 had been calculated from the prominent peak (311) by using Bragg's equation:

$$
\mathrm{a}=\mathrm{d}_{\mathrm{llkl}} \sqrt{\mathrm{h}^{2}+\mathrm{k}^{2}+\mathrm{l}^{2}}
$$

h, k, 1 are the indices of the mentioned planes. Lattice constants of all samples prepared in investigation are listed in Table 1. The lattice constant is smaller than pure $\mathrm{MgFe}_{2} \mathrm{O}_{4}$ and increases with the addition of $\mathrm{Ce}$ and $\mathrm{Gd}$ ions.

This is attributed to the large difference between cation radii of $\mathrm{R}^{3+}$ and $\mathrm{Fe}^{3+}$ owing to the removal of rare-earth ions from the spinel lattice. The size of crystal was evaluated by measuring the FWHM of the most intense peak (311) mentioned in Table 1 using the Debye Scherrer's formula [14].

$$
D=\frac{0.94 \lambda}{\beta \cos \theta}
$$

Table.1. XRD, Cation distribution of $\mathrm{MgCe}_{\mathrm{x}} \mathrm{Gd}_{\mathrm{y}} \mathrm{Fe}_{2-\mathrm{x}-\mathrm{y}} \mathrm{O}_{4}$.

\begin{tabular}{|c|c|c|c|}
\hline \multicolumn{2}{|c|}{ Sample } & \multirow{2}{*}{$\begin{array}{c}\text { Lattice } \\
\text { constant }\left(\mathrm{A}^{\mathrm{o}}\right)\end{array}$} & $\begin{array}{c}\text { Cry stalline } \\
\text { size }(\mathrm{nm})\end{array}$ \\
\hline 0.001 & $\mathrm{y}$ & 8.5418 & 53.24 \\
0.012 & 0.002 & 8.5193 & 53.26 \\
0.016 & 0.002 & 8.5160 & 53.28 \\
0.018 & 0.002 & 8.5152 & 53.78 \\
\hline
\end{tabular}

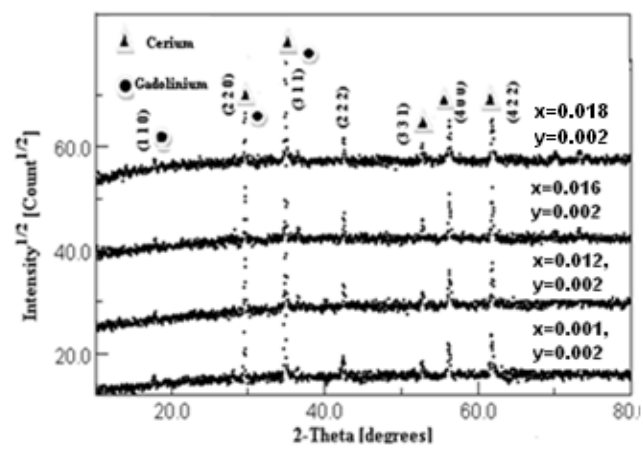

Fig1 XRD patterns of sintered $\mathrm{MgCe}_{\mathrm{x}} \mathrm{Gd}_{\mathrm{y}} \mathrm{Fe}_{2-\mathrm{x}-\mathrm{y}} \mathrm{O}_{4}$ ferrite with different Ce-Gd content $\mathrm{x}=0.001,0.012,0.016,0.018$ and $y=0.002$.

\subsection{SEM analysis}

SEM Fig. 2, 3, 4 and 5 show the microstructure of sintered specimen. The Unsubstituted speci-men Fig $2[1,5]$ showed the presence of a monophasic homogeneous microstructure with an average grain size $0.42 \mathrm{~nm}$ in the encircled region[1,5].Where as Ce- Gd doped specimen's Fig 3-5 show a bi-phasic microstructure constituted of dark ferrite matrix grains and small whitish grain at the grain junction/boundary (encircled region), according to Sattar et, al [2] the rare earth ions occupy either the iron positions or go to the grain boundaries. However we have to exclude the probability that the rare earth ions occupy the $\mathrm{B}-$ site of $\mathrm{Fe}^{3+}$ ions. This is due to the fact that the tetrahedral sites are small to be occupied by the large rare earth ions which have large ionic radius. Of course the probability of occupancy in the octahedral site (Bsite) by the rare earth ions will increase with in decrease in ionic radius $\mathrm{R}$. The grain size of matrix phase was maximum in $x^{1 / 4} 0.016$ composition Fig 5. Here the relatively lower grain size of ferrite matrix was in $\mathrm{x}^{1 / 4} 0.018$ compositions may be due to the grain growth inhibition caused by $\mathrm{Ce}-\mathrm{Gd} \mathrm{FeO}_{3}$ seen in Fig3-5, as compared to Fig2.

The grains in the unsubstituted sample are inhomogeneous [1] i.e., the grains are affected by certain stress, while the grains for the Ce-Gd substituted $\mathrm{Mg}$ Ferrite samples are nearly homo-geneous due to the decrease of stress. The photographs confirm these results that the stability has increased for the substituted samples.

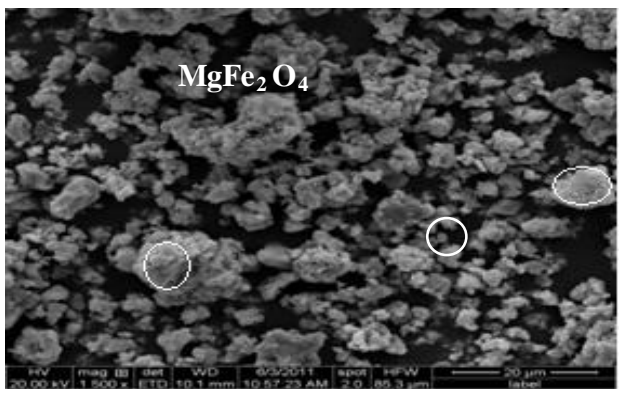

Fig.2 $\mathrm{MgFe}_{2} \mathrm{O}_{4}$ 


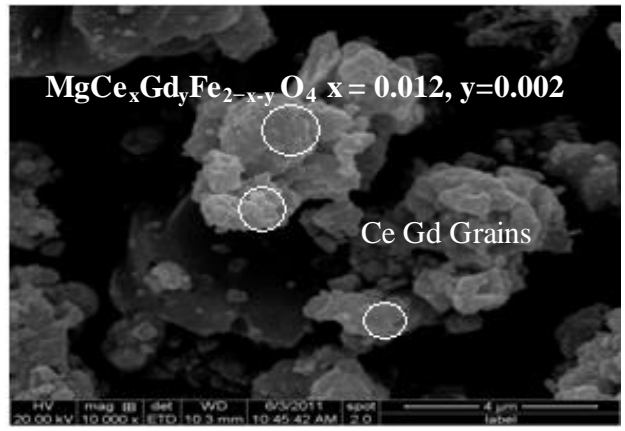

Fig.3 $\mathrm{MgCe}_{\mathrm{x}} \mathrm{Gd}_{\mathrm{y}} \mathrm{Fe}_{2-\mathrm{x}-\mathrm{y}} \mathrm{O}_{4} \quad \mathrm{x}=0.012, \mathrm{y}=0.002$

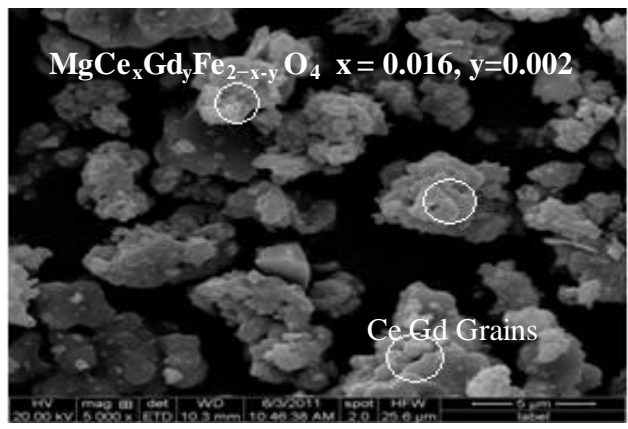

Fig.4 $\mathrm{MgCe}_{\mathrm{x}} \mathrm{Gd}_{\mathrm{y}} \mathrm{Fe}_{2-\mathrm{x}-\mathrm{y}} \mathrm{O}_{4} \quad \mathrm{x}=0.016, \mathrm{y}=0.002$

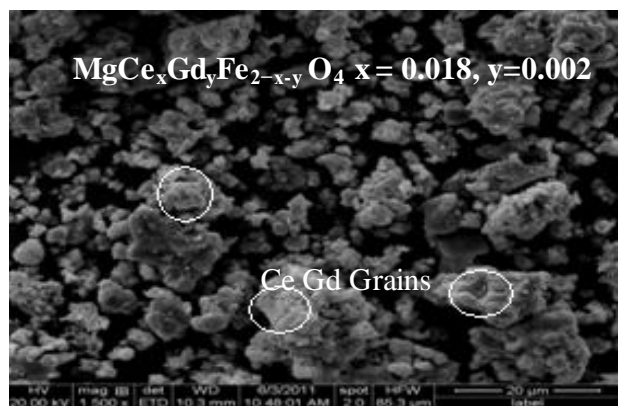

Fig.5 $\mathrm{MgCe}_{\mathrm{x}} \mathrm{Gd}_{\mathrm{y}} \mathrm{Fe}_{2-\mathrm{x}-\mathrm{y}} \mathrm{O}_{4} \mathrm{x}=0.018, \mathrm{y}=0.002$

\subsection{FTIR study}

The study of far-infrared spectra is an important tool to get the information about the position of ions in the crystal. FTIR absorption spectra of the samples in the range of 362.59 $570.89 \mathrm{~cm}^{-1}$ are given in Fig.6. The spectra show two major absorption bands in the given frequency range. The high and low frequency absorption bands $\left(v_{1}, v_{2}\right)$ are observed in a frequency range of $3.62 \times 10^{4} \mathrm{~m}^{-1}$ to $4.08 \times 10^{4} \mathrm{~m}^{-1}$ and 5.65 $\times 10^{4} \mathrm{~m}^{-1}$ to $5.70 \times 10^{4} \mathrm{~m}^{-1}$, which is attributed to tetrahedral and octahedral complexes $\mathrm{Fe}^{3+} \mathrm{O}^{2-}$ These two bands have been reported by Waldron [15] in spinel structure of ferrite. No shift of absorption band $v_{1}$ is observed. The absorption band $v_{2}$ is slightly shifted to a higher frequency side with addition of $\mathrm{R}$ ions and is attributed to increase in bond length on the B-site [16]. This suggests that the rare-earth ions occupy the B-site. The difference in frequencies between $v_{1}$ and $v_{2}$ is due to changes in bond length $\left(\mathrm{Fe}^{3+} \mathrm{O}^{2-}\right)$ at tetrahedral and octahedral sites [17]. The broadening of the $\mathrm{v}_{2}$ band is observed in rare-earth added $\mathrm{MgFe}_{2} \mathrm{O}_{4}$, which suggests the occupancy of rare-earth ions on the B-sites [18].

In nano particles, the inter-ionic separation may face an extension due to less number of structural matters in the surrounding of each particle. Thus the nano size of the ferrite particles and ultimate change of the nature of ions in the respective size could have caused reduction of magnetization in $\mathrm{MgFe}_{2} \mathrm{O}_{4}$. Thus in nano regime, the cation distribution. Fig
6 show that the change in $v_{1}$ and $v_{2}$, the value of change in the difference of frequency decrease with the increase in the values of $\mathrm{Ce}-\mathrm{Gd}$. The change in retentivity and change of coercive force was seen with the change in concentration. Table. 2 gives the absorption frequencies for different doping values of cerium content.

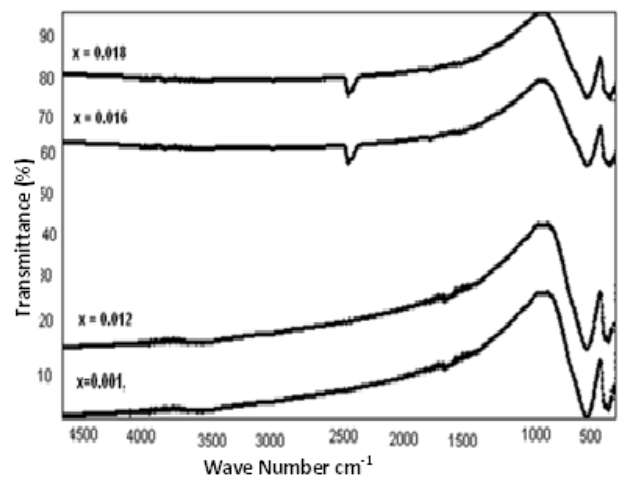

Fig.6 FTIR absorption spectra of the samples.

Table 2.FTIR to show the rare-earth ions occupation in the

\begin{tabular}{|c|c|c|c|}
\multicolumn{4}{|c|}{ B-site } \\
\cline { 1 - 2 } $\mathrm{Mg} \mathrm{Ce}_{\mathrm{x}} \mathrm{Gd}_{\mathrm{y}} \mathrm{Fe}_{2-\mathrm{x}-\mathrm{y}} \mathrm{O}_{4}$ & \multicolumn{2}{|c|}{ Absorption/cm } \\
$\mathrm{x}$ & $\mathrm{y}$ & $v_{1}$ & $v_{2}$ \\
\hline 0.001 & 0.002 & 570.89 & 408.88 \\
\hline 0.012 & 0.002 & 565.10 & 406.95 \\
\hline 0.016 & 0.002 & 568.96 & 362.59 \\
\hline 0.018 & 0.002 & 565.10 & 364.52 \\
\hline
\end{tabular}

\subsection{Hysteresis studies}

Fig. 7-10 shows the variation in saturation magnetization (Ms) for the different $\mathrm{x}$ values of $\mathrm{Mg} \mathrm{Ce} \mathrm{Cd}_{\mathrm{y}} \mathrm{Fe}_{2-\mathrm{x}-\mathrm{y}} \mathrm{O}_{4}$ ferrite, the saturation magnetization (Ms) value increases with increase in the value of $x$. The increasing Cerium content induced a polar-to-non polar phase transition. Within the polar region, a rhombohedral and two orthorhombic modifications of $\mathrm{MgCe}_{\mathrm{x}} \mathrm{Gd}_{\mathrm{y}} \mathrm{Fe}_{2-\mathrm{x}-\mathrm{y}} \mathrm{O}_{4}$ were found. It was shown that Ce-Gd substitution resulted in the appearance of spontaneous magnetization, which was significantly enhanced upon the composition-driven transition from a rhombohedral to an orthorhombic phase.

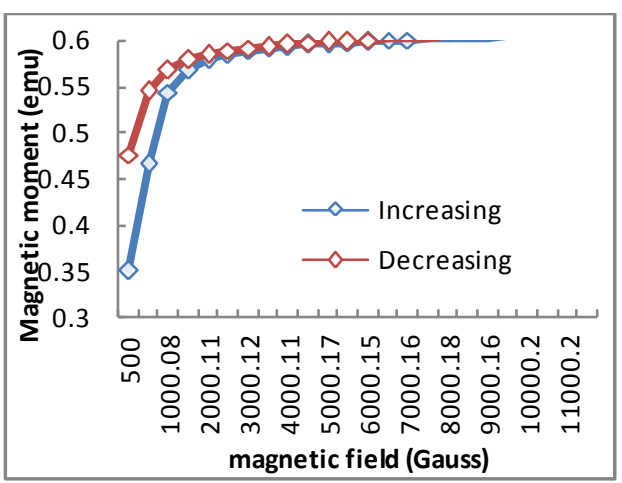

Fig. $7 \mathrm{Mg} \mathrm{Ce}_{\mathrm{x}} \mathrm{Gd}_{\mathrm{y}} \mathrm{Fe}_{2-\mathrm{x}-\mathrm{y}} \mathrm{O}_{4}$ ferrites $\mathrm{x}=0.001$ $\mathrm{y}=0.002$ Saturation magnetization $(\mathrm{Ms})$ 


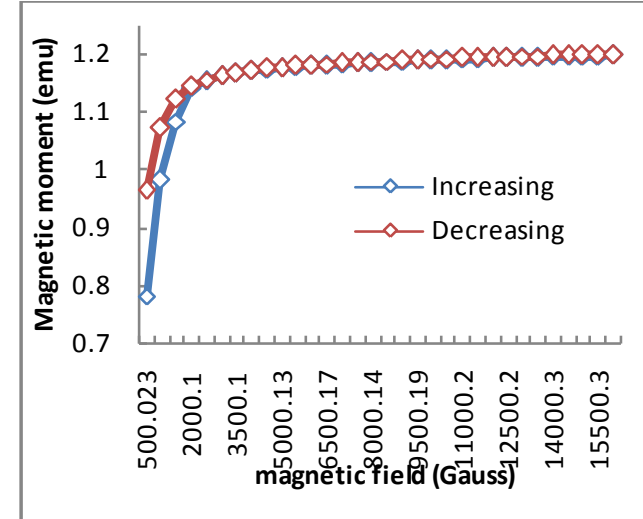

Fig.8 $\mathrm{Mg} \mathrm{Ce}_{\mathrm{x}} \mathrm{Gd}_{\mathrm{y}} \mathrm{Fe}_{2-\mathrm{x}-\mathrm{y}} \mathrm{O}_{4}$ ferrites $\mathrm{x}=0.012 \mathrm{y}=0.002$ Saturation magnetization $(\mathrm{Ms})$

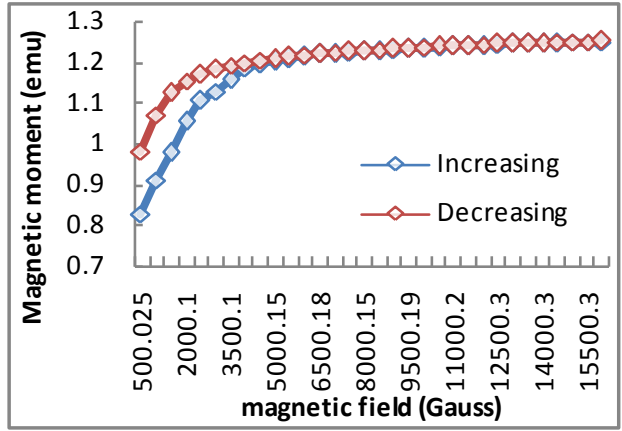

Fig.9 $\mathrm{Mg} \mathrm{Ce} \mathrm{Gd}_{\mathrm{y}} \mathrm{Fe}_{2-\mathrm{x}-\mathrm{y}} \mathrm{O}_{4}$ ferrites $\mathrm{x}=0.016$ $\mathrm{y}=0.002$ Saturation magnetization $(\mathrm{Ms})$

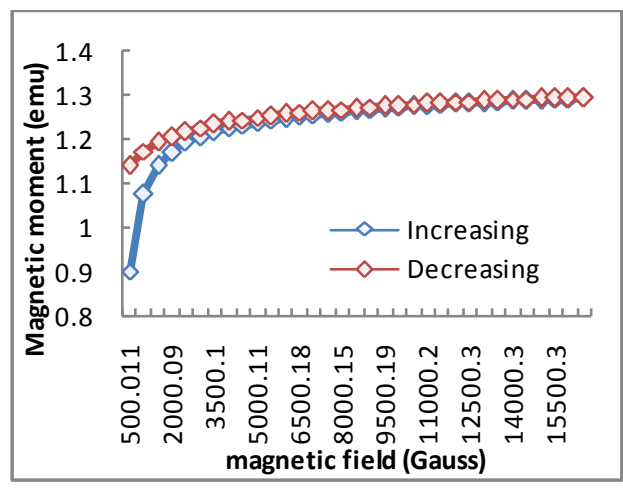

Fig.10 $\mathrm{Mg} \mathrm{Ce}_{\mathrm{x}} \mathrm{Gd}_{\mathrm{y}} \mathrm{Fe}_{2-\mathrm{x}-\mathrm{y}} \mathrm{O}_{4}$ ferrites $\mathrm{x}=0.018 \mathrm{y}=0.002$ Saturation magnetization $(\mathrm{Ms})$

Table 3 Coercivity, Magnetic saturation, Magnetic moment and Retentivity of $\mathrm{MgCe}_{\mathrm{x}} \mathrm{Gd}_{\mathrm{y}} \mathrm{Fe}_{2-\mathrm{x}-\mathrm{y}} \mathrm{O}_{4}$

\begin{tabular}{|c|c|c|c|c|c|}
\hline \multicolumn{2}{|c|}{$\begin{array}{c}\text { Mg Cex Gdy } \\
F_{2-x-Y} \mathbf{O}_{\mathbf{4}}\end{array}$} & $\begin{array}{c}\text { Magnetic } \\
\text { Saturatio } \\
\text { n(emu) }\end{array}$ & $\begin{array}{c}\text { Magnetic } \\
\text { moment }\end{array}$ & $\begin{array}{c}\text { Coercivi } \\
\text { ty }\end{array}$ & $\begin{array}{c}\text { Retenti } \\
\text { vity } \\
\mathbf{x 1 0}\end{array}$ \\
\hline$X$ & $Y$ & 0.6119 & 0.0221 & 64.58 & 6.895 \\
\hline 0.001 & 0.002 & 1.2032 & 0.0434 & 38.68 & 7.452 \\
\hline 0.012 & 0.002 & 1.258 & 0.0454 & 90.66 & 19.67 \\
\hline 0.016 & 0.002 & 1.2998 & 0.0469 & 102.9 & 23.39 \\
\hline 0.018 & 0.002 & & & & \\
\hline
\end{tabular}

Table 3 show that the change in retentivity and change of coercive force with change in concentration respectively. The coercive force show linear increase initially and later shows a gradual decrease with the increase in the doping concentration table 3. The values of magnetic parameters such as $\mathrm{M}_{\mathrm{S}}, \mathrm{H}_{\mathrm{C}}, \mathrm{M}_{\mathrm{R}}$ of nano particles of $\mathrm{Mg} \mathrm{Ce}_{\mathrm{x}} \mathrm{Gd}_{\mathrm{y}} \mathrm{Fe}_{2-\mathrm{x}-\mathrm{y}}$
$\mathrm{O}_{4}$ obtained from the VSM data are $0.6119 \mathrm{emu}, 64.582 \mathrm{G}$, $0.068 \mathrm{emu}$ respectively. As reported $[19,20] \mathrm{M}_{\mathrm{s}}$ value for bulk particle of $\mathrm{MgFe}_{2} \mathrm{O}_{4}$ as $27 \mathrm{emu} / \mathrm{g}$.Therefore the increase in saturation magnetization can be attributed to the effect of nano regime on it. The difference in the value of $M_{S}$ can be explained in the light of cation distribution. Any change in the concentration and nature of the ions in $\mathrm{A}$ and $\mathrm{B}$ site should cause resultant magnetization to be different from reported one [20].

\subsection{EDAX}

The EDAX spectra (Fig. 11 to Fig14) obtained from the center of grain boundary of $\mathrm{MgFeO}_{3}$ phase indicated the presence of mainly $\mathrm{Mg}$ and $\mathrm{Fe}$ along with small amount of $\mathrm{Ce}$, and $\mathrm{Gd}$. The grain size of ferrite matrix phase as well as the $\mathrm{MgFeO}_{3}$ phase increased with increasing the $\mathrm{Gd}-\mathrm{Ce}$ substitutions. The EDAX spectra (Fig.11,12, 13 and 14) were obtained from the center of $\mathrm{Mg}$ substituted Sm ferrite grains indicated the presence of small concentration of $\mathrm{Mg}$ inside the grains at $1.5 \mathrm{keV}$, where as $\mathrm{Ce}$ grains are seen in between the energy range of $4.5 \mathrm{keV}$ and $6.5 \mathrm{keV}, \mathrm{Gd}$ grains are seen in between the energy range of $5.5 \mathrm{keV}$ and $8 \mathrm{keV}$ where as the Fe peaks are seen at $6.2 \mathrm{keV}$ and $7 \mathrm{keV}$.

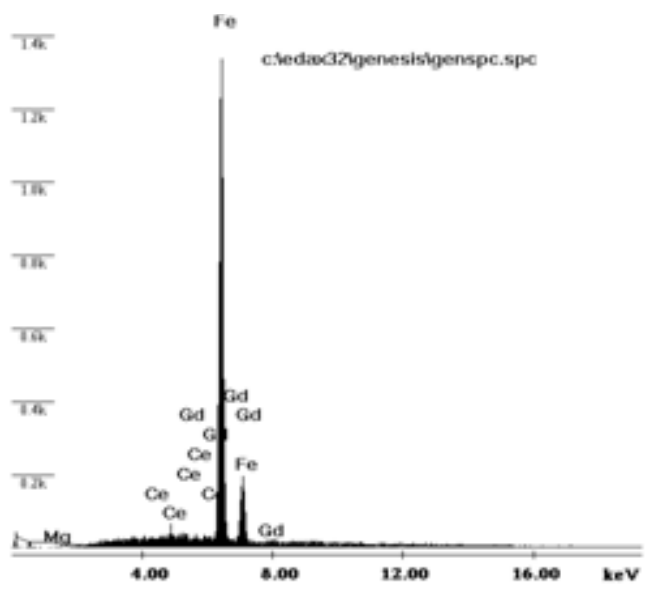

Fig.11 EDAX pattern for $\mathrm{MgCe} \mathrm{Cd}_{\mathrm{y}} \mathrm{Fe}_{2-\mathrm{x}-\mathrm{y}} \mathrm{O}_{4} \mathrm{x}=0.012$ $\mathrm{y}=0.002$

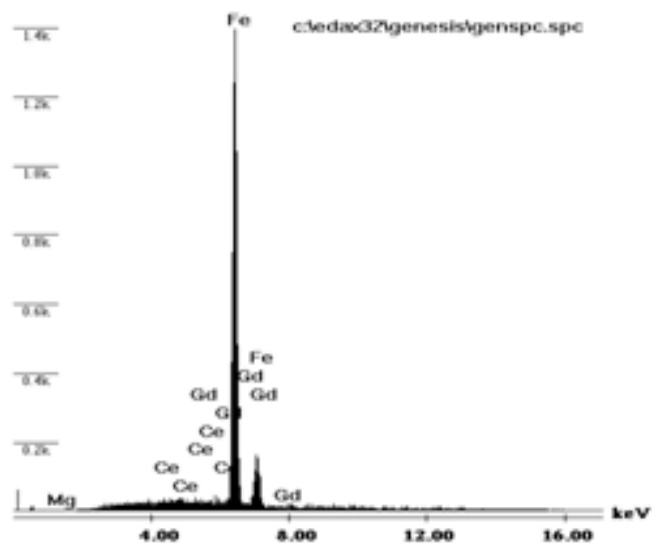

Fig.12 EDAX pattern for $\mathrm{Mg} \mathrm{Ce} \mathrm{ed}_{\mathrm{y}} \mathrm{Fe}_{2-\mathrm{x}-\mathrm{y}} \mathrm{O}_{4} \mathrm{x}=0.014$ $\mathrm{y}=0.002$ 


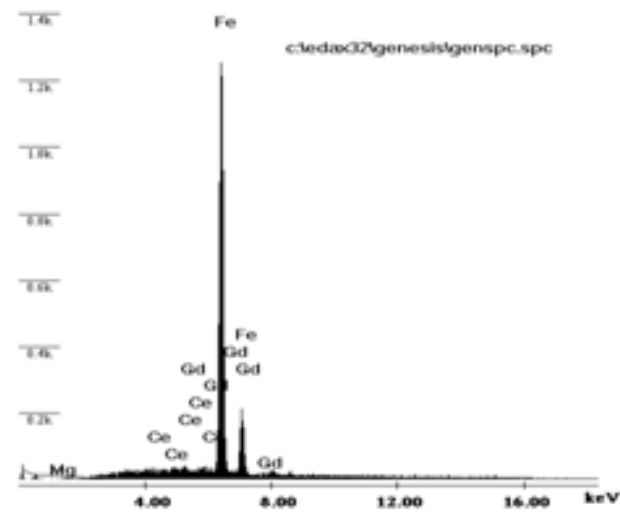

Fig.13 EDAX pattern for $\mathrm{Mg} \mathrm{Ce}_{\mathrm{x}} \mathrm{Gd}_{\mathrm{y}} \mathrm{Fe}_{2-\mathrm{x}-\mathrm{y}} \mathrm{O}_{4} \mathrm{x}=0.016$ $\mathrm{y}=0.002$

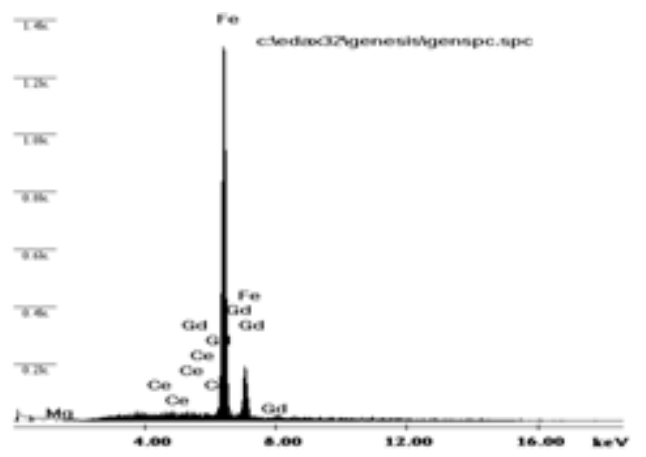

Fig.14 EDAX pattern for $\mathrm{MgCe}_{\mathrm{x}} \mathrm{Gd}_{\mathrm{y}} \mathrm{Fe}_{2-\mathrm{x}-\mathrm{y}} \mathrm{O}_{4} \mathrm{x}=0.018$ $\mathrm{y}=0.002$

\subsection{Electrical Properties}

The dielectric constant of the sintered samples $\left(\mathrm{Mg} \mathrm{Ce}_{\mathrm{x}} \mathrm{Gd}_{\mathrm{y}}\right.$ $\mathrm{Fe}_{2-x-y} \mathrm{O}_{4} \mathrm{x}=0.001,0.012,0.016,0.018$ and $\mathrm{y}=0.002$ ) over the microwave frequency range from $.02 \mathrm{M}-.02 \mathrm{GHz}$ are shown in figure 19. The maximum value of dielectric constant 2.334, was observed for the sample $\mathrm{x}=0.001$ and minimum was 1.7398 for the sample, $\mathrm{x}=0.018$.

The high value of dielectric constant of the sample $\mathrm{x}=0.001$ as compared to $\mathrm{x}=0.018$ may be explained on the basis of the structural changes associated with the magnesium ferrite when the grain size is reduced to nanometer order. Magnesium ferrite crystallizes into a cubic close-packed arrangement of oxy gen ions. It belongs to the class of ferrites with an inverse spinel structure having structural formula, $\mathrm{Fe}^{3+}\left[\mathrm{Mg}^{2+} \mathrm{Fe}^{3+} \mathrm{Ce}^{3+} \mathrm{Gd}^{3+}\right] \mathrm{O}_{4}$ [21]. The metal ions given in the square bracket are called octahedral (B site) ions and that outside the square bracket are called tetrahedral (A site) ions. The magnesium ions $\left(\mathrm{Ce}^{3+} \mathrm{Gd}^{3+}\right)$ together with half of the iron ions $\left(\mathrm{Fe}^{3+}\right)$ occupy the $\mathrm{B}$ site and the remaining half of the iron ions reside in A site. The presence of $\mathrm{Ce}^{3+}$ and $\mathrm{Gd}^{3+}$ ions gives rise to $\mathrm{p}$-type carriers (holes) where as $\mathrm{Fe}^{2+}$ and $\mathrm{Fe}^{3+}$ ions produce n-type carriers (electrons). Therefore, both electrons and holes that are present in the B sites are due to the presence of $\mathrm{Ni}$ and $\mathrm{Fe}$ ions. Since only iron ions are present in A sites, electrons are the carriers in A sites.

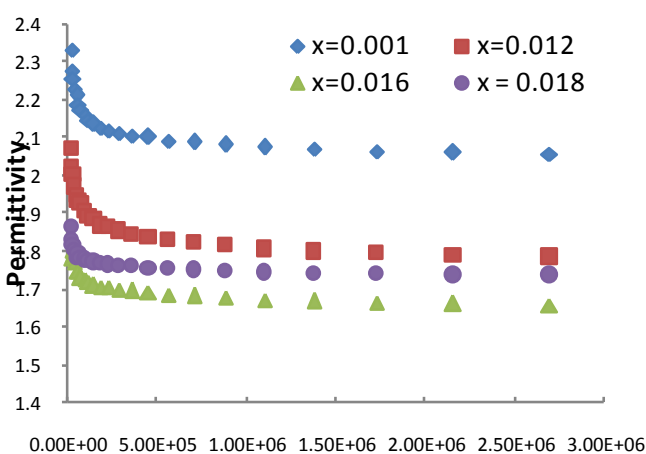

Frequency $\mathrm{KHz}$

Fig.19 Permittivity study for $\mathrm{Mg} \mathrm{Ce}_{\mathrm{x}} \mathrm{Gd}_{\mathrm{y}} \mathrm{Fe}_{2-x-y} \mathrm{O}_{4}$ $\mathrm{x}=0.001,0.012,0.016,0.018 \mathrm{y}=0.002$.

The distance between the ions in A sites $(0.357 \mathrm{~nm})$ is larger than the distance between the ions in B site $(0.292 \mathrm{~nm})$ [22]. Also, the degree of covalence for the A site ions is higher than that of the B site ions. All the above factors result in a high activation energy for the A sites compared to the B sites. Hence, in ordinary magnesium ferrite with an inverse spinel structure the electron movement in $\mathrm{B}$ sites dominates compared to that in A sites. In figure it has been observed that the value of relative permittivity $\left(\varepsilon_{\mathrm{r}}\right)$ decreases with the increase in Ce concentration, this shows that the as prepared material can be used for developing patch antenna.

\section{CONCLUSION}

From the above experimental results, it is clearly evident that the nano size of the ferrite particles has caused increase in magnetization in Ce-Gd doped $\mathrm{MgFe}_{2} \mathrm{O}_{4}$. Since Saturation magnetization and coercive force increases and relative permittivity decreases with the increase in Ce-Gd. Further note the dopen concentration should be increased further to decrease the relative permittivity $\left(\varepsilon_{\mathrm{r}}\right)$ and decrease the magnetic saturation value in its hysteresis property. these parameters will be very useful for the application of the ferrite materials in the antenna construction. This change will be also suitable for reducing the size of the antenna.

\section{ACKNOWLEDGEMENTS}

One of the authors Dr.VasantNaidu, would like to thank Dr.V.R.K.Murthy, Professor, IIT Madras for his valuable suggestions. Author Dr.VasantNaidu wishes to thank the DRDO, New Delhi.

\section{REFERENCES}

[1] A. Pradeep, P .Priy adharsini, G.Chandrasekaran., Solgel route of nano particles of $\mathrm{MgFe}_{2} \mathrm{O}_{4}$ and XRD,FTIR and VSM study, [J] Journal of Magn. Mag. Mater, 2008, 320, 2779.

[2] Ü.Özgür, Y.Alivov, and H.Morkoç, "Microwave Ferrites, Part 1: Fundamental Properties", [J] J. Mater. Sci.: Materials in Electronics, 2009, 1-169.

[3] L.B Kong., et.al, Magneto-Dielectric Properties of Mg$\mathrm{Cu}-\mathrm{Co}$ Ferrite Ceramics: II Electrical, Dielectric, and Magnetic Properties, [J] J. Am. Ceram. Soc., 2007, 7, 2104-2112.

[4] E.Melagiriyappa, H.S Jayanna, B.K.Chougule., Dielectric behavior and ac electrical conductivity study of $\mathrm{Sm}^{3+}$ substituted $\mathrm{Mg}-\mathrm{Zn}$ ferrites , [J] Journal of Materials Chemistry and Phy sics, 2008 , 112, 68-73. 
[5] Vasant Naidu..et.al , Magnetic properties of Nickel, Cerium doped Zinc ferrite, International Journal of Computer Applications (0975 - 8887),2011.

[6] Wilhelm Van Aulock (Ed.), [M] Handbook of microwaves ferrites Materials Academic Press,Newy ork,London, 1965.

[7]. O.S. Josyulu, J. Shobanadri , [M] Phy. Status Sol. , 1980, 59, 323.

[8] V.R.K. Murthy, J.Shobanadri, [M] Phy.Status Sol., $1976,36,133$

[9] M.L. Khan and Z.J. Zhang, [J] Appl. Phys. Lett., 2001, 78,3651 .

[10] A.A Sattar.., et.al, Rare Earth Doping Effect on the Electrical Properties of Cu-Zn Ferrites, [J] J. Phys. IV France 1997, 7.

[11] K.T. Mathew and Raveendranath U. Nair, "Waveguide cavity perturbation method for measuring complex permittivity of water", Microwave Opt. Technol. Lett., vol.6, No.2, pp. 104-106, 1993.

[12] B.D Cullity., [M] Elements of X-Ray Diffraction, Addison Wesley Pub. Co. Inc., London 1967, 96.

[13] B.R Karche., B.VKhasbardar., and Vaingankar A.S., Xray, SEM and magnetic properties of $\mathrm{Mg}$-Cd ferrites, [J] J. Magn. Magn.Mater., 1997,168,292.
[14] R.D Waldron., Infrared spectroscopy of ferrites, [J] Phy Rev., 1955, 1727.

[15] O.M Hemeda., Effect of sintering on X-Ray and IR spectral behaviour of the $\mathrm{MnAl}_{\mathrm{x}} \mathrm{Fe}_{2-\mathrm{x}} \mathrm{O}_{4}$ ferrite system, [J] J. Magn. Magn.Mater., 1996,156,1,29-38.

[16] M.Z Said., et.al , Structural, Electrical and Infrared Studies of $\mathrm{Ni}_{0.7} \mathrm{Cd}_{0.3} \mathrm{Sm}_{\mathrm{x}} \mathrm{Fe}_{2-\mathrm{x}} \mathrm{O}_{4}$ Ferrite, [J] Turk J Phys $2007,31,41-50$.

[17] R.V Upadhay ay., et,.al ,Gd-substituted ferrite ferrofluid: a possible candidate to enhance pyro magnetic coefficient [J]J. Magn.Magn. Mater.,1999,201, 129.

[18] Smith.,Wijin.H.P.J,Ferrites, [M] Cleaver-Hume Press, 1959.

[19] R.G Kulkarni., H Joshi., Comparison of magnetic properties of $\mathrm{MgFe}_{2} \mathrm{O}_{4}$ prepared by wet-chemical and ceramic methods, [J] Journal.Solid State Chem, 1986 $, 64,2,141$.

[20] V..R.K.Murthy,B.Viswanathan, [M] Ferrite Materials, Narosa Publishing House, 1990.

[21] Ponpandian N, Balay a P and Naray anasamy A N 2002 J. Phys.: Condens. Matter 143221

[22] Chinnasamy C N, Narayanasamy A, Ponpandian N, Chattopadhy ay K, Gueralt H and Greneche J M 2000 J. Phys. Condens. Matter 127795. 